\title{
GLIWICE RADIOCARBON DATES X
}

\author{
MIECZYSŁAW F PAZDUR, ROMUALD AWSIUK, \\ ANDRZEJ BLUSZCZ, TOMASZ GOSLAR, ANNA PAZDUR, \\ ADAM WALANUS, and ANDRZEJ ZASTAWNY \\ Institute of Physics, Silesian Technical University \\ Krzywoustego 2, PL-44-100 Gliwice, Poland
}

The following list contains all age measurements of paleoenvironmental samples made from 1978 to the end of 1982 for the IGCP 158 Project "Paleohydrological changes in the temperate zone in the last 15,000 years," Subproject B "Lake and mire environments" (Berglund, 1979), initiated by Bjorn Berglund and Leszek Starkel in 1976. The aim of this project was to reconstruct environmental changes related to climate and human activity in the temperate zone of Asia, Europe, and North America. Broad environmental reconstructions will be based upon a network of reference sites representing the natural geographic regions, distinguished by their geology, climate, vegetation, and other natural factors, according to Berglund (1979). The subdivision of Poland into 29 paleoecological units according to Ralska-Jasiewiczowa (1982) is presented in table 1, and in figure 1 where reference sites dated by ${ }^{14} \mathrm{C}$ in our lab are also indicated.

In this paper, we present a list of ${ }^{14} \mathrm{C}$ dates from 12 reference sites (figure 1). The site at Lake Wielkie Gacno (subregion 11a, fig 1; Hjelmroos, 1981 a,b; 1982) was ${ }^{14} \mathrm{C}$ dated in Lund (Håkansson, 1980). A brief report on the activities of the Polish Group of the IGCP 158B Project was given by Ralska-Jasiewiczowa (1981).

Ages are reported as conventional ${ }^{14} \mathrm{C}$ dates in years before AD 1950 , uncorrected for isotopic fractionation and based on the Libby half-life of $5568 \mathrm{yr}$. Errors quoted $( \pm 1 \sigma)$ include estimated overall standard deviations of count rates of the unknown sample, contemporary standard and background (Pazdur \& Walanus, 1979). The ANU Sucrose Secondary Radiocarbon Dating Standard was used as the modern reference standard, correlated with $95 \%$ of ${ }^{14} \mathrm{C}$ activity of NBS Oxalic Acid, normalized to $\partial^{13} C=$ $-19 \%$ wrt PDB, according to Polach (1979) and Currie and Polach (1980). Laboratory equipment and techniques have been described (Pazdur et al, 1982 ; 1983), the only exception being chemical pretreatment of peat samples. Unless otherwise stated, peat samples were pretreated only with $\mathrm{HCl}$, as suggested by Håkansson (1976). Sample descriptions and comments are based on information provided by submitters.

\section{ACKNOWLEDGMENTS}

The authors are indebted to Henry A Polach, Australian Natl Univ, Canberra, for submitting ANU Sucrose Standard. Significant financial support from the Committee of Quaternary Research, Polish Academy of Sciences, Warsaw, is acknowledged. Thanks go to Helena Skorupka for her technical assistance during sample pretreatment. 
TABLE 1

Subdivision of Poland into paleoecological regions and subregions

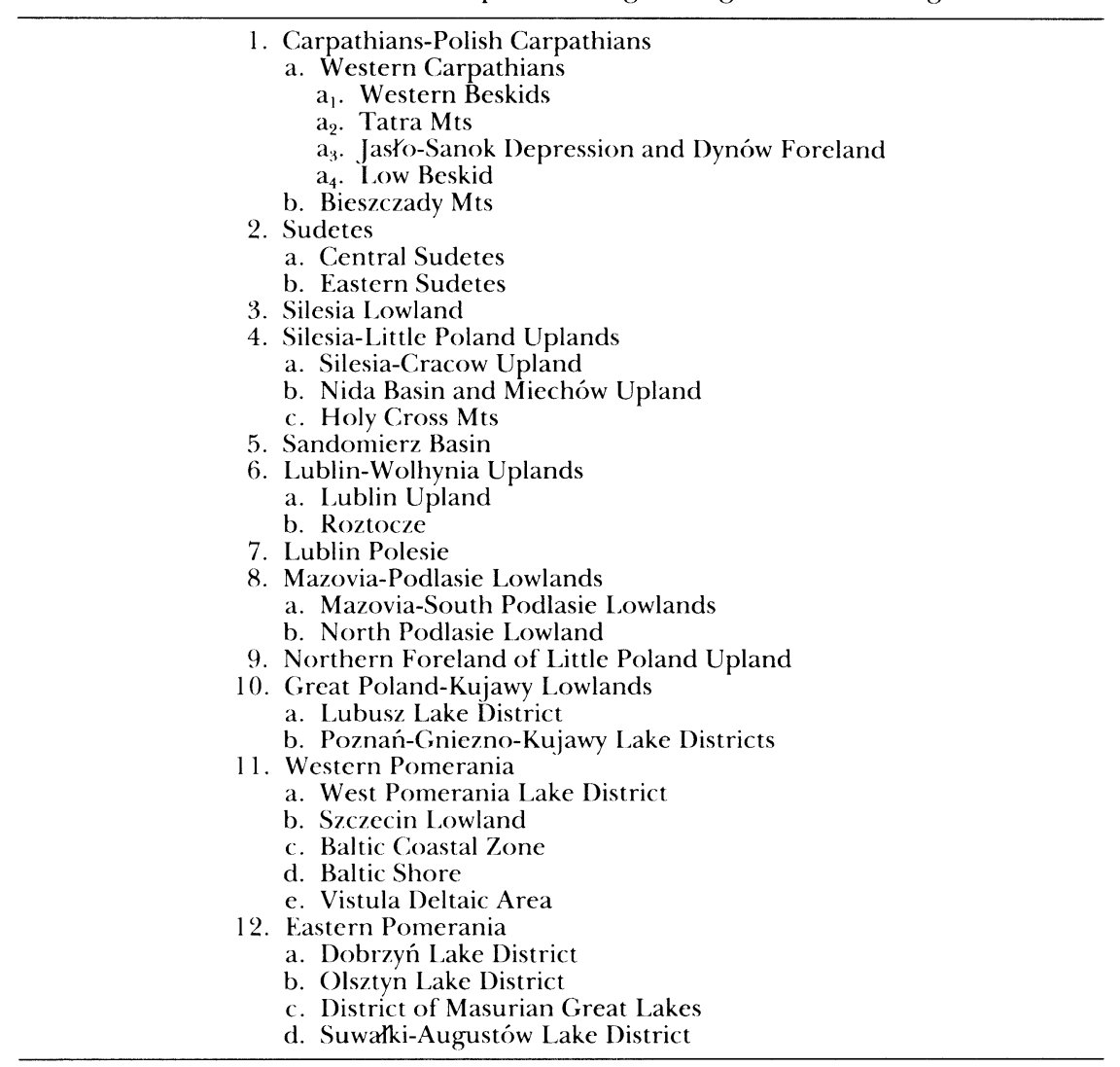

\section{SAMPLE DESCRIPTIONS}

\section{PALEOENVIRONMENTAL SAMPLES}

Region 1. Carpathians ( fig I)

$$
\text { a. Tatra Mts }
$$

\section{Puścizna Rekowiańska profile PR series}

Peat from Puścizna Rẹkowiańska bog, Orawa-Nowy Targ Basin, ca $12 \mathrm{~km} \mathrm{~W}$ of Nowy Targ $\left(49^{\circ} 29^{\prime} \mathrm{N}, 19^{\circ} 49^{\prime} \mathrm{E}\right)$, alt 654 to $658 \mathrm{~m}$ asl; coll June 1980 and subm 1980 and 1982 by Andrzej Obidowicz, Inst Bot, Pol Acad Sci, Cracow. Earlier pollen studies of this site were made by Koperowa (1962); present palynol age determinations are by AO. 


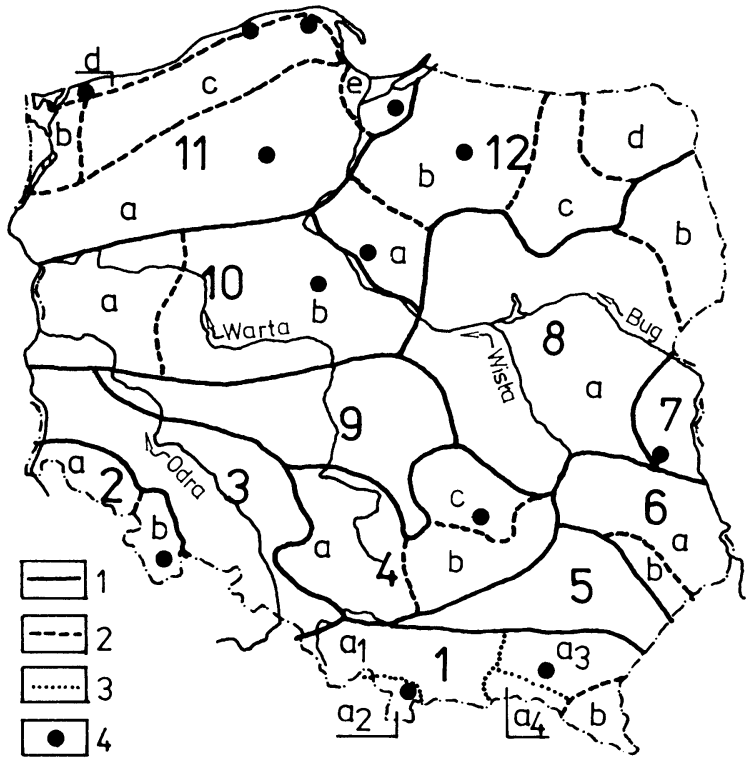

Fig 1. Subdivision of Poland into palaeoecological regions (Ralska-Jasiewiczowa, 1982). $1 \boxminus$-boundaries of main regions, $2 \mathrm{E}$ and $3 \boxminus-$ boundaries of sub-regions, $4 \square-$ location of ref sites.

Gd-1565. PR VII

$3670 \pm 70$

Brown medium decomposed Sphagnum peat, depth 3 to $3.1 \mathrm{~m}$, Subatlantic/Sub-boreal boundary.

Gd-2050. PR VI

$4540 \pm 150$

Same, depth 3.8 to $3.9 \mathrm{~m}$, Sub-boreal/Atlantic boundary.

Gd-1570. PR V

$4890 \pm 60$

Brown medium decomposed Eriophorum-Sphagnum peat, depth 4.4 to $4.5 \mathrm{~m}$, Atlantic period.

Gd-985. PR IV

$7350 \pm 160$

Dark-brown strongly decomposed Eriophorum peat, depth 5.6 to $5.7 \mathrm{~m}$, Atlantic period.

Gd-1501. PR III

$8570 \pm 90$

Dark-brown strongly decomposed fen peat with fragments of wood, depth 6.7 to $6.8 \mathrm{~m}$, Boreal period.

Gd-986. PR II

$8800 \pm 160$

Same, depth 6.8 to $6.9 \mathrm{~m}$, Boreal/Pre-boreal boundary.

Gd-1500. PR I

$8960 \pm 80$

Same, depth 7.1 to $7.15 \mathrm{~m}$, Pre-boreal period. 
$a_{3}$. Jasło-Sanok Depression and Dynów Foreland

Ref area in Jasiołka $\mathrm{R}$ valley comprises 2 sites with lacustrine sediments, consisting of marl, peat, clay, and gyttja, studied by Antoni Wójcik, Geol Inst, Carpathian Branch, Cracow, and Krystyna Harmata and Kazimierz Szczepanek. Previous paleobot studies of this area by Szafer (1948) indicate late glacial and Holocene sediments.

\section{Tarnowiec profile TAR series}

Peat and wood from fossil lake sediments in Tarnowiec $\left(49^{\circ} 44^{\prime} \mathrm{N}, 21^{\circ}\right.$ 32' E), Jasiołka R terrace, alt 230m asl. Coll Aug 1979 and subm 1982 by Antoni Wójcik.

Gd-1483. TAR VIIA

$\mathbf{2 0 4 0} \pm \mathbf{5 0}$

Clayey peat, depth 25 to $30 \mathrm{~cm}$. Comment $(\mathrm{KS})$ : deforestation of area, beginning of Sub-atlantic period.

\section{Gd-966. TAR VIIB}

$1950 \pm 60$

Duplicate run on same sample.

\section{Gd-1484. TAR VI}

$3930 \pm 60$

Brown peat, depth 56 to $60 \mathrm{~cm}$. Comment (KS): highest values of Fagus and Abies pollen, Sub-boreal period.

\section{Gd-964. TAR V}

$4240 \pm 90$

Peat with fragments of wood, depth 96 to $100 \mathrm{~cm}$. Comment $(\mathrm{KS})$ : pollen spectrum shows presence of beech and hornbeam forest, beginning of Subboreal period.

Gd-1482. TAR IV

$5230 \pm 80$

Peat with wood fragments, depth $1.3 \mathrm{~m}$. Comment $(\mathrm{KS})$ : large amounts of Corylus, Tilia, and Ulmus pollen, typical for Atlantic period, with unexpectedly large amounts of Fagus pollen.

Gd-1481. TAR III

$9380 \pm 80$

Peat, depth $1.55 \mathrm{~m}$. Comment (KS): pollen spectrum indicates pine forest with elm and spruce, typical for younger Pre-boreal period.

Gd-962. TAR II

$9840 \pm 100$

Wood fragments from marl layer at depth $1.8 \mathrm{~m}$. Comment (KS): presence of larch and Swiss stone pine (Pinus cembra) forests with pine, Pre-boreal period.

\section{Gd-967. TAR I}

$11,190 \pm 140$

Peat with marl and faunal remains, depth $2 \mathrm{~m}$. Comment (KS): pollen spectrum containing large amounts of Pinus pollen with Pinus cembra, Larix, Betula nana, and Gramineae, and Cyperaceae confirms Alleröd age. Comment (MFP): peat from depth 1.4 to $1.45 \mathrm{~m}$, this profile, was dated to $7930 \pm 110 ; \mathrm{Gd}-767(\mathrm{R}, 1983$, v 25, p 854). 
Region 2. Sudetes

\section{b. Eastern Sudetes}

\section{Zieleniec profile $\mathrm{ZL}$ series}

Peat from continuous profile at ref site Zieleniec $\left(50^{\circ} 21^{\prime} \mathrm{N}, 16^{\circ} 25^{\prime} \mathrm{E}\right)$, Kłodzko Basin, $8 \mathrm{~km} \mathrm{~S}$ of Duszniki Zdrój, S part of Lower Silesia, Bystrzyckie Mts, E Sudetes, alt $750 \mathrm{~m}$ asl (Kuźniewski, 1959). Core taken Oct 1978 by Andrzej Obidowicz; samples subm 1979 by Magdalena RalskaJasiewiczowa; preliminary pollen analysis by Ewa Madeyska. Site was previously studied by Stark (1936) and Kuźniewski (1962).

Gd-658. ZL VI

$$
2720 \pm 80
$$

Undecomposed Eriophorum peat, depth 2.45 to $2.55 \mathrm{~m}$, end of Subboreal or beginning of Sub-atlantic period.

Gd-661. ZL V

$3700 \pm 60$

Light brown peat, medium decomposition, depth 3.25 to $3.35 \mathrm{~m}$, Subboreal period.

Gd-1092. ZL IV

$5370 \pm 70$ period.

Well-decomposed Eriophorum peat, depth 5.05 to $5.15 \mathrm{~m}$, Atlantic

Gd-1091. ZL III

$8390 \pm 80$

Transitional peat layer with bark fragments, medium decomposition, depth 6.85 to $6.95 \mathrm{~m}$, younger part of Boreal period.

Gd-1090. ZL II

$8700 \pm 80$

Well-decomposed dark brown peat with wood fragment, depth 7.19 to $7.29 \mathrm{~m}$, older part of Boreal period.

Gd-1089. ZL I

$8740 \pm 100$ period.

Well-decomposed dark brown peat, depth 7.29 to $7.38 \mathrm{~m}$, Pre-boreal

Region 4. Silesia-Little Poland Uplands

c. Holy Cross Mts

\section{Stopiec profile II series}

Peat from continuous profile Słopiec II taken from bog in small trough, probably oxbow lake, in Belnianka $\mathrm{R}$ valley, Słopiec village $\left(50^{\circ} 47^{\prime}\right.$ N, $20^{\circ} 47^{\prime} \mathrm{E}$ ), near Daleszyce, ca $20 \mathrm{~km}$ E of Kielce, Daleszyce Basin, Holy Cross Mts, alt 248m asl. Coll Nov 1978 and subm 1979, 1980, and 1982 by Kazimierz Szczepanek, Inst Bot, Bot Garden, Jagellonian Univ, Cracow.

Gd-768. Słopiec II/7

Light brown Sphagnum-Eriophorum-Ericaceae peat, depth 27.5 to $32.5 \mathrm{~cm}$, local pollen assemblage zone (PAZ) Rumex-Cerealia. 
Gd-774. Słopiec II/18

$370 \pm 60$

Transition between Sphagnum-Eriophorum-Ericaceae and SphagnumEriophorum peat with distinct layer of Ericaceae shoots at $85 \mathrm{~cm}$, depth 82.5 to $87.5 \mathrm{~cm}$, PAZ Cannabis-Fagus-Pinus, overlying boundary with PAZ PinusBetula-Quercus.

Gd-701. Słopiec II/23

$480 \pm 70$

Sphagnum-Eriophorum peat with pieces of wood, depth 107.5 to $112.5 \mathrm{~cm}$, PAZ Pinus-Betula-Quercus.

\section{Gd-1157. Stopiec II/29}

$1090 \pm 60$

Brown swamp peat, depth 137.5 to $142.5 \mathrm{~cm}$, boundary of PAZ PinusBetula-Quercus and Carpinus-Fagus-Abies.

Gd-983. Stopiec II/33

$1940 \pm 60$

Same, depth 162.5 to $167.5 \mathrm{~cm}$, PAZ Capinus-Fagus-Abies.

Gd-1241. Słopiec II/40

$2710 \pm 60$

Same, depth 192.5 to $197.5 \mathrm{~cm}$, boundary of PAZ Carpinus-Fagus-Abies and Alnus-Carpinus, Sub-atlantic/Sub-boreal boundary.

Gd-775. Słopiec II/45

$3450 \pm 80$

Same, depth 217.5 to $222.5 \mathrm{~cm}$, PAZ Alnus-Carpinus.

Gd-1158. Słopiec II/49

$\mathbf{3 6 5 0} \pm \mathbf{5 0}$

Same, depth 237.5 to $242.5 \mathrm{~cm}$, same PAZ, overlying boundary with PAZ Corylus-Tilia-Picea.

Gd-1505. Stopiec II/52

$4660 \pm 70$

Same, depth 252.5 to $257.5 \mathrm{~cm}$, PAZ Corylus-Tilia-Picea.

Gd-1506. Słopiec II/55

$5710 \pm 80$

Same, depth 267.5 to $272.5 \mathrm{~cm}$, same PAZ.

Gd-1507. Stopiec II/60

$6690 \pm 80$

Same, depth 292.5 to $297.5 \mathrm{~cm}$, same PAZ, overlying boundary with PAZ Corylus-Alnus.

Gd-776. Stopiec II/70

$9090 \pm 100$

Same, depth 342.5 to $347.5 \mathrm{~cm}$, boundary of PAZ Corylus-Alnus and Pinus-Ulmus, Atlantic/Boreal boundary.

Gd-703. Słopiec II/80

$9330 \pm 150$

Brown swamp peat with numerous rhizomes and shoots of swamp plants and pieces of wood; depth 392.5 to $397.5 \mathrm{~cm}$, "boundary of PAZ Pinus-Ulmus and Salix-Betula.

Gd-700. Słopiec II/81

$9620 \pm 120$

Same, adjacent layer, depth 397.5 to $400 \mathrm{~cm}$, PAZ Salix-Betula. 
Gd-702. Słopiec II/85

Same, depth 417.5 to $422.5 \mathrm{~cm}$, same PAZ, overlying boundary with PAZ Populus-Polypodiaceae, overlying Pre-boreal/Younger Dryas boundary.

Gd-1508. Stopiec II/95

$10,090 \pm 120$

Blackish-brown swamp peat with rhizomes of swamp plants and numerous seeds of Menyanthes and single pieces of wood; depth 467.5 to $472.5 \mathrm{~cm}$, PAZ Larix-Juniperus-Pinus.

Gd-704. Słopiec II/104

$10,280 \pm 210$

Same, depth 512.5 to $515 \mathrm{~cm}$, basal layer of peat at contact with fine sands, same PAZ.

Region 7. Lublin Polesie

Reference site: $\mathbf{L u k c z e}$

Łukcze in W part of $\ell$ ęczno Lake Dist, SW part of Lublin Polesie (Wilgat, 1953; Maruszczak, 1966) comprises small eutrophic Lake Kukcze and mire at $\mathrm{W}$ shore of lake $\left(51^{\circ} 30^{\prime} \mathrm{N}, 23^{\circ} \mathrm{E}\right)$. Two profiles (TŁ \& $\measuredangle$ III), ca $10 \mathrm{~m}$ apart and ca $20 \mathrm{~m}$ from shore, were taken in May 1979, subm 1979 and 1981 by Krystyna Bałaga, Inst Earth Sci, Maria Curie Skłodowska Univ, Lublin.

Lake Łukcze has two parts linked by channel (Bałaga, 1982, fig 1, p 10-11), with NE, E, and S lake shores covered with alder, and fragments of devastated pine Vaccinio myrtilli-Pinetum forest and mixed Pino-Quercetum forest in SE part. From SW and NW, community of Salici-Franguletum connects lake with mire covered by fragments of Caricetum lasiocarpae, $C$ limosae, $C$ diandrae, and Sphagnetum medio-rubelli. Eleven local pollen assemblage zones were defined, 5 based on data from Lukcze TX and $\ell$ ukcze III profiles.

\section{Lukcze profile TL series}

Profile T屯 consists of well-decomposed black-brown sedge-moss peat, max thickness $3.5 \mathrm{~m}$.

Gd-1175. Lukcze TL-1

$\mathbf{9 8 0} \pm \mathbf{5 0}$

Depth 50 to $55 \mathrm{~cm}$, local PAZ $\downarrow-10$, transition between subzones e and $\mathrm{f}$, with decreases of Carpinus, Quercus, Plantago lanceolata, Rumex, and Urtica pollen, and first appearance of Secale cereale pollen.

Gd-1178. Lukcze TL-2

$6420 \pm 70$

Depth 90 to $95 \mathrm{~cm}$, local PAZ X-8 with dominance of Ulmus, Quercus, and Corylus, and first appearance of Plantago lanceolata and cereals. Dates first appearance of Carpinus and Fagus.

Gd-1179. Lukcze TL-3

$7790 \pm 70$

Depth 165 to $170 \mathrm{~cm}$, boundary of local PAZs L-7 and -8 with increase of Quercus and Alnus and decrease of Pinus pollen, and first appearance of Pteridium aquilinum spores. 
Depth 250 to $255 \mathrm{~cm}$, boundary of local PAZs $X_{-}-3$ and $t_{-}-4$, with decrease in Artemisia pollen and empirical limit of Ulmus (after Bałaga, 1982, p 15), end of Younger Dryas period.

Gd-1182. Lukcze TL-5

$10,930 \pm 90$

Iepth 280 to $285 \mathrm{~cm}$, boundary of local PAZs L-2 and $九-3$ with increase of Artemisia and decrease of Gramineac pollen. Comment (KB): beginning of Younger Dryas period; date younger than expected.

\section{Lukcze profile L-III series}

Core X-III is composed of silt with some gray brown gyttja at base, overlain by sedge-moss peat, peaty gyttja, calcarcous gyttja, and at top, sedge-moss brown peat of varying degrees of decomposition; max depth of organic sediments, $450 \mathrm{~cm}$.

Gd-1180. Lukcze L-III-1

$9080 \pm 90$

Black-brown peaty gyttja, organic matter $91 \%$, depth 250 to $260 \mathrm{~cm}$, boundary of local PAZs $4-5$ and $4,-6$, at max rise of Corylus, end of calcareous gyttja sedimentation, beginning of Boreal period.

\section{Gd-822. Lukcze L-III-2}

$10,660 \pm 210$

Black-gray detritus-calcareous gyttja, depth 340 to $350 \mathrm{~cm}$, organic matter content 52\%, carbonate 9\%, local PAZ $4-3$ with max rise of Artemisia pollen up to $30 \%$. Comment (MFP): undersized, diluted, date is probably too old because of hard-water effect, indicated by presence of Polamogeton and Myriophyllum (Pazdur, 1982).

\section{Gd-824. Lukcze L-III-3}

$10,680 \pm 190$

Black-brown peaty gyttja, depth 380 to $390 \mathrm{~cm}$, underlying calcareous gyttja, organic matter $72 \%$, no carbonates. Local PAZ K-3, sample dates transition between peaty gyttja and detritus-calcareous gyttja and beginning of carbonate sedimentation. Comment (MFP): undersized, diluted.

\section{Gd-825. Lukcze L-III-4}

$11,160 \pm 110$

Black-brown peaty gyttja, organic matter ca 70\%, no carbonates, depth 400 to $410 \mathrm{~cm}$. Boundary of local PAZs $\mathrm{L}-2$ and $\mathrm{K}-3$. Comment (MFP): correlates fairly well with Gd-1182: 10,930 \pm 90 , and dates beginning of Younger Dryas period.

\section{Gd-1183. Kukcze K-III-5}

Black-brown sedge moss peat with gyttja and silt, organic matter $35 \%$, depth 425 to $430 \mathrm{~cm}$, boundary of local PAZs $t_{-}-()$and $t_{-1}-1$ with decrease in Betula and Salix pollen and increase in Pinus and Gramineae percentages, beginning of organic matter sedimentation and mire development.

Region 10. Great-Poland-Kujawy Lowlands

b. Poznań-Gniezno-Kujawy Lake District 


\section{Gopło profile GI series}

Peat and gyttja from core taken in bog in subglacial channel, $500 \mathrm{~m} \mathrm{SW}$ of Gopło Lake shore, in Mielnica Duża village (52 $33^{\prime} \mathrm{N}, 18^{\circ} 30^{\prime} \mathrm{E}$ ), Kujawy Uplands, alt $78 \mathrm{~m}$ asl. Organogenic sediments, $10.25 \mathrm{~m}$ thick, overlying Pleistocene sands, are composed of detrital gyttja and basal peat layer, overlain by ca $8.5 \mathrm{~m}$ thick series of calcareous gyt ja with shells and upper peat layer. Coll March 1980 and subm by Barbara Jankowska, Inst Biol, Mikołaj Kopernik Univ, Toruń (Jankowska, 1981).

Gd-1263. Gopło G1

$460 \pm 50$

Slightly decomposed peat, depth $20 \mathrm{~cm}, 1.67 \% \mathrm{CaCO}_{3}$, weight loss on ignition (LWI) $76.8 \%$.

Gd-1264. Gopło G2

$\mathbf{1 0 1 0} \pm \mathbf{5 0}$

Slightly decomposed peat, depth $60 \mathrm{~cm}, 6.29 \% \mathrm{CaCO}_{3}$, LWI $83.3 \%$.

Gd-798. Gopło G3

$1370 \pm 60$

Well-decomposed black-brown peat, depth $120 \mathrm{~cm}, 10.07 \% \mathrm{CaCO}_{3}$, LWI $52.8 \%$.

\section{Gd-799. Goplo G10}

$13,040 \pm 140$

Organic matter with fine sand, depth 10.15 to $10.25 \mathrm{~m}, 2.51 \%$ of $\mathrm{CaCO}_{3}$, LWI 0.19\%. Comment (MFP): undersized, diluted.

General Comment (BJ): preliminary results of pollen analysis indicate Subatlantic age for upper peat layer and Oldest Dryas age for lowermost organic layer (Jankowska, 1981).

Region 11. Western Pomerania

\section{c. Baltic Coastal Zone}

\section{Reference site: $\dot{Z}$ arnowiec}

Zarnowiec covers three loci in neighborhood of Lake Zarnowiec, chosen to obtain pollen material representative of past local and regional plant cover. Two loci lie in extensive Lake Żarnowiec channel surrounded by moraine hills covered by beech and oak forest, representing regional features. Third locality representing local features is in Darzlubie Forest in tunnel valley of Lake Dobre (Latałowa, 1981a). For pollen analysis and ${ }^{14} \mathrm{C}$ dating 2 cores were taken with Russian "Instorf" corer $10 \mathrm{~cm}$ diam. Eight pollen assemblage zones were distinguished, which can probably be applied regionally (Latałowa, 1981a,b; 1982a,b).

\section{Żarnowiec profile $\dot{Z} a r / 76$ series}

Highly decomposed peat from core Żar/76, loc 1 (Latałowa, 1982a, p 51 , fig 3) ca $2 \mathrm{~km} \mathrm{~S}$ of lake shore in bog in Lake Zarnowiec tunnel valley $\left(54^{\circ}\right.$ $43^{\prime} \mathrm{N}, 18^{\circ} 7^{\prime} \mathrm{E}$ ), alt $5 \mathrm{~m}$ asl, Kaszuby Coast. Coll 1976 and subm 1978 by Małgorzata Latałowa, Dept Plant Ecol, Inst Biol, Gdańsk Univ, Gdynia. Present peatbog vegetation is devastated, meadow communities of Cirsio- 
Polygonetum type are dominant, with swamp spp and some low-moor sp occurring in places.

Gd-685. Żar/76/45-50

$2400 \pm 60$

From depth 45 to $50 \mathrm{~cm}$, Iron age settlement phase, pollen assemblage zone (PAZ) Quercus-Carpinus.

Gd-598. Żar/76/107-112

$3230 \pm 70$

From depth 107 to $112 \mathrm{~cm}$, settlement phase of Early Bronze age, PAZ Quercus-Corylus.

Gd-1030. $\dot{Z}$ ar/76/142-152

$4030 \pm 60$

From depth 142 to $152 \mathrm{~cm}$, rational Carpinus limit, settlement phase of Neolithic period, PAZ Quercus-Corylus.

Gd-595. Żar/76/191-200

$5460 \pm 60$

From depth 191 to $200 \mathrm{~cm}$, overlying first pollen of Plantago lanceolata and first settlement phase, PAZ Quercus-Corylus, close to boundary with PAZ Tilia-Ulmus-Pinus.

Gd-686. $\dot{\text { Zar }} / \mathbf{7 6} / \mathbf{2 4 5 - 2 5 0}$

$6460 \pm 100$

From depth 245 to $250 \mathrm{~cm}$, distinct increase of Quercus, Atlantic period, PAZ Tilia-Ulmus-Pinus.

Gd-596. Żar/76/288-298

$8090 \pm 70$

From depth 288 to $298 \mathrm{~cm}$, somewhat below rational Tilia limit, Boreal/Atlantic boundary, just above boundary of PAZs Tilia-Ulmus-Pinus and Corylus-Pinus.

Gd-1029. $\dot{\text { Zar }} / 76 / 343-352$

$9070 \pm 70$

From depth 343 to $352 \mathrm{~cm}$, rational Corylus limit, Pre-boreal/Boreal boundary, boundary of PAZ Corylus-Pinus and Pinus sub-zone of PAZ Pinus-Betula.

Gd-1031. $\dot{Z}$ ar/76/387-397

$10,130 \pm 120$

From depth 387 to $397 \mathrm{~cm}$, Late Glacial/Holocene boundary, decline of Juniperus and NAP marking boundary of PAZ Juniperus-Pinus-Betula with sub-zone Pinus-Betula-Filipendula of PAZ Pinus-Betula.

\section{Darżlubie Forest profile PDarż/78 series}

Slightly decomposed peat from loc 3 in Darżlubie Forest, peat bog in tunnel valley of Lake Dobre, core PDarz $/ 78$ taken ca $1 \mathrm{~km} \mathrm{SW}$ of lake shore $\left(54^{\circ} 42^{\prime} \mathrm{N}, 18^{\circ} 10^{\prime} \mathrm{E}\right)$, ca $6 \mathrm{~km} \mathrm{SE}$ of loc 1 , alt $80 \mathrm{~m}$ asl. Coll and subm 1978 by Małgorzata Latałowa. Lake valley is ca $100 \mathrm{~m}$ wide with slopes somewhat raised and grown over with pine and oak-pine woods, wet meadow communities of order Molinietalia cover surface of peat bog with typical low-moor and transition bog sp. 
Gd-1032. PDarż/78/23-33

$$
1120 \pm 50
$$

From depth 23 to $33 \mathrm{~cm}$, decrease of Carpinus and expansion of Fagus, expansion of Early Medieval settlement, PAZ Pinus-Fagus-Juniperus, overlying boundary with PAZ Quercus-Carpinus.

Gd-599. PDarż/78/87-98

$$
2310 \pm 60
$$

From depth 87 to $98 \mathrm{~cm}$, below rational Fagus limit, Sub-boreal/Subatlantic boundary PAZ Quercus-Carpinus.

Gd-1033. PDarz/78/113-123

$$
2770 \pm 60
$$

From depth 113 to $123 \mathrm{~cm}$, expansion of Carpinus, distinct decrease of Quercetum Mixtum, first appearance of Lusation culture settlement indicators, PAZ Quercus-Carpinus.

Gd-1058. PDarż/78/183-193

$4030 \pm 70$

From depth 183 to $193 \mathrm{~cm}$, rational Carpinus limit (?), first pollen of Plantago lanceolata, Neolithic settlement phase, PAZ Quercus-Corylus.

Gd-1124. PDarż/78/201-205

$5070 \pm 70$

From depth 201 to $205 \mathrm{~cm}$, decrease of Ulmus, distinct increase of Quercus and Corylus, PAZ Tilia-Ulmus-Pinus.

Gd-1125. PDarż/78/220-225

$6780 \pm 80$

From depth 220 to $225 \mathrm{~cm}$, distinct change in local vegetation, very strong increase of concentration of sporomorphs, PAZ Tilia-Ulmus-Pinus.

Gd-625. PDarì/78/253-263

$7900 \pm 110$

From depth 253 to $263 \mathrm{~cm}$, just below rational Tilia limit and Boreal/ Atlantic boundary, PAZ Corylus-Pinus, underlying boundary with PAZ Tilia-Ulmus-Pinus, marked by fall in Corylus percentage.

Gd-626. PDarż/78/303-313/a

$8890 \pm 100$

From depth 303 to $313 \mathrm{~cm}$, changes in local vegetation, PAZ CorylusPinus, Boreal period.

Gd-1113. PDarż/78/303-313/b

$8780 \pm 90$

Duplicate run on 2 nd portion of same sample.

Gd-1126. PDarż/78/327-332

$9170 \pm 110$

From depth 327 to $332 \mathrm{~cm}$, increase of Ulmus and Quercus, decrease of heliophytes, Pinus sub-zone of PAZ Pinus-Betula, underlying boundary with PAZ Corylus-Pinus. Comment (ML): upper boundary of PAZ Pinus-Betula is synchronous in profiles Żar/76, PDarz/76 and PDarż/78 and falls at 9100 BP.

Gd-1154. PDarż/78/332-337

$8990 \pm 90$ level.

From depth 332 to $337 \mathrm{~cm}$, control run on sample from adjacent 
Gd-1059. PDarz/ 78/350-358

$9080 \pm 90$

From depth 350 to $358 \mathrm{~cm}$, rational Corylus limit, Pre-boreal/Boreal boundary.

Gd-1060. PDarì/78/373-381

$9840 \pm 110$

From depth 373 to $381 \mathrm{~cm}$, decrease of Juniperus, boundary of PAZ Pinus-Betula and Juniperus-Pinus-Betula. Comment (ML): this boundary in profile Zar/76 is dated to $10,130 \pm 120 \mathrm{BP}$; Gd-1031, above.

General Comment (ML): pollen diagrams from Lake Żarnowiec area differ considerably despite fact that loci are within $5 \mathrm{~km}$ of one another. This results from local (loc 3) vs regional (loc 1) types of pollen spectra. Nevertheless, pollen assemblage zones are parallel and should have regional applications. Seven settlement phases were distinguished based on cultural indicators and plants related to human activity. First 3 phases correspond to Neolithic, 4 th to II/III period of Bronze age, phases 5 and 6 correspond to Kaszubian Group of Lusatian and East Pomeranian cultures (Halstatt C and D). Last, 7th phase corresponds to Early Middle age habitation.

\section{d. Baltic Shore}

\section{Reference site: Niechorze}

Niechorze, in W part of Western Pomerania, consists of two profiles with peat and peaty slime deposits; $1 \mathrm{st}$ in cliff ca $1.7 \mathrm{~km} \mathrm{~W}$ of Niechorze village $\left(54^{\circ} 5^{\prime} \mathrm{N}, 15^{\circ} 3^{\prime} \mathrm{E}\right)$, 2nd in small bog ca $1.8 \mathrm{~km} \mathrm{SW}$ of 1 st profile. Samples coll April 1978 and subm by Krystyna Kopczyńska-Lamparska, Inst Fundamental Geol, Warsaw Univ, Warsaw.

\section{Niechorze Cliff I series}

Peat and peaty slime deposits from small lake basin exposed in cliff cut mainly in two horizons of Vistulian tills (Kopczyńska-Lamparska, 1974). Organic deposits overlying fluvioglacial sands and silts continue $30 \mathrm{~m}$ along cliff and about same distance to $\mathrm{S}$, their thickness in cliff is $2.85 \mathrm{~m}$ and decreases to $0.5 \mathrm{~m}$ at lake shore, $17 \mathrm{~m} \mathrm{~S}$ of cliff. Present samples taken from profile ca $1 \mathrm{~m}$ from profile studied in 1974 (Kopczyńska-Lamparska, 1976, figs 2 \& 3; Pazdur, Pazdur, \& Zastawny, 1979, p 168-169; Brykczyńska, $1978)$.

Gd-1111. Niechorze I-1

$3340 \pm 60$

Peat, depth 32 to $37 \mathrm{~cm}$.

Gd-1099. Niechorze I-3

$5910 \pm 80$

Peaty silt, uppermost layer overlain by peat, depth 42 to $49 \mathrm{~cm}$.

Gd-1112. Niechorze I-7

$9330 \pm 120$ $79 \mathrm{~cm}$.

Peaty silt overlying series of silts with mollusk shells, depth 72 to 
Gd-782. Niechorze I-8:sol

$13,430 \pm 150$

Peaty silt with mollusk shells, lowermost part of layer, depth 160 to $164 \mathrm{~cm}$. Comment (MFP): alkali-soluble fraction dated.

Gd-1245. Niechorze I-8:ins

$12,260 \pm 120$

Same sample, insoluble fraction.

Gd-1107. Niechorze I-9

$11,880 \pm 110$ $193 \mathrm{~cm}$

Peat, uppermost part of peat layer overlying peaty silt, depth 191 to

Gd-1108. Niechorze I-10

$11,980 \pm 130$

Peaty, lowermost part of same layer.

Gd-1109. Niechorze I-11

$12,150 \pm 100$

Peaty silt, depth 195 to $201 \mathrm{~cm}$.

Gd-673. Niechorze I-12

$12,010 \pm 150$

Peaty silt, lowermost part of same layer, depth 201 to $210 \mathrm{~cm}$.

General Comment (MFP): Gd-782 and -1245 older than expected probably due to hard-water effect.

\section{Niechorze profile $\mathbf{s} 1$ series}

Peat from profile sl from bog developed above lacustrine deposits in small basin on morainic plateau.

Gd-1096. Niechorze s1-2

$3660 \pm 60$

Depth 1 to $1.15 \mathrm{~m}$.

Gd-1097. Niechorze s1-4

$4330 \pm 80$

Depth 2 to $2.15 \mathrm{~m}$.

Gd-1098. Niechorze s1-5

$4600+70$

Depth 2.55 to $2.7 \mathrm{~m}$.

Reference area: Gardno-Leba Lowlands

Gardno-Łeba Lowlands are separate, morphologically and genetically differentiated physiographic unit in central part of Western Pomerania, bordered in $\mathrm{N}$ part by Baltic Sea shoreline and in $\mathrm{S}$ part by diluvial plateau, with three coastal lakes in $\mathrm{N}$ part, where sand bars are partly covered by migrating dunes. Gardno- Łeba Lowlands are under supervision of Słowiński Natl Park. Ref area is represented by 5 sites, 3 in coastal sand bars and 2 in large mires SW of Łebsko Lake, studied by Kazimierz Tobolski, Inst Quaternary Research, Adam Mickiewicz Univ, Poznań (Tobolski, 1982, fig 1, p 132). 


\section{Sarbsko Bay Bar series}

Wood from individual trunks (Quercus sp, id by Kazimierz Tobolski) from top series of organic sediments on beach or in dune cliff on Sarbsko Bay Bar near Łeba-Neptun $\left(54^{\circ} 46^{\prime} \mathrm{N}, 17^{\circ} 34^{\prime} \mathrm{E}\right)$, ca $1 \mathrm{~km} \mathrm{E}$ of $Ł e b a \mathrm{R}$ mouth to Baltic. Coll May 1978 and subm by Kazimierz Tobolski for studies of post-Littorina succession of local vegetation in Sarbsko Bar (Tobolski, 1979; 1981, p 104-106; 1982; Tobolski et al, 1980).

Gd-573. Leba-Neptun 1/78

$1220 \pm 50$

From outer part of horizontal oak trunk, $55 \mathrm{~cm}$ diam, with 160 annual rings, lying on oak forest humus horizon containing $62 \%$ of Quercus pollen grains, overlain by coastal dune sands, depth ca $85 \mathrm{~cm}$. Comment (KT): date confirms earlier dating of humus horizon, thought to be rejuvenated due to younger humic acids penetration or rootlets $(1430 \pm 140$ : Gd-418, R, 1979, v 21, p 165). This horizon was previously expected to be of late Subboreal age or slightly younger.

Gd-1008. Leba-Neptun 2/78

$1060 \pm 50$

From outer part of horizontal root of oak trunk with ca 120 annual rings found on surface of organic sediments, ca $10 \mathrm{~m} \mathrm{~W}$ of trunk 1/78.

Gd-1006. Leba-Neptun 3/78

$1120 \pm 50$

From outer part of root of oak trunk with ca 100 annual rings, from surface of organic sediments, ca $5 \mathrm{~m} \mathrm{E}$ of trunk 1/78.

General Comment (KT): dating of Łeba-Neptun oak trunks proves that destruction of oak forest occurred in 9th century AD. Decay of primary oak forests was gradual and took place at different times, which, compared with fossil soils in area, argues for anthropogenic causes of changes within primary vegetation of bar areas.

\section{Gardno Bay Bar series}

Wood from outer part of individual trunks of Quercus sp forming two oak cemeteries related to subfossil peat layers on beech in E part of Gardno Bay Bar $\left(54^{\circ} 41^{\prime} \mathrm{N}, 17^{\circ} 8^{\prime} \mathrm{E}\right)$. Coll May 1978 and subm by Kazimierz Tobolski.

Gd-1005. MG-1/78

$2130 \pm 50$

From in situ trunk, diam $70 \mathrm{~cm}$.

Gd-1004. MG-2/78

$\mathbf{2 8 6 0} \pm \mathbf{5 0}$

From in situ trunk, diam $120 \mathrm{~cm}$, found ca $350 \mathrm{~m}$ W of trunk $1 / 78$.

General Comment (KT): dates indicate non-uniform decay of oak forests over this area. First date refers to period when oak trees were destroyed in central part of $\ell$ eba Bar; 2nd one is related to older events from earlier period of Bronze age (Tobolski et al, 1980). Other date of interest to problem was obtained on oak charcoals from fossil soil near Czołpino, same area (Gd421; $3340 \pm 130$, R, 1979, v 21, p 165; Borówka \& Tobolski, 1979). 


\section{Leba Bay Bar series}

Wood and bark fragments related to fossil soil levels in area of mobile coastal dunes, central part of Leba Bay Bar $\left(54^{\circ} 45^{\prime} \mathrm{N}, 17^{\circ} 24^{\prime} \mathrm{E}\right)$. Coll and subm 1978 by Kazimierz Tobolski. Dated as part of complex systematic studies including paleo- and phytogeography of Gardno-Leba Lowlands (Tobolski, 1981, p 93-100), evolution of coastal dunes (Tobolski, 1975; 1980; 1981, p 100-103), decay of pine and beech forests (Wojterski, 1964; Tobolski, 1979), partly in connection with IGCP 158B project.

Gd-570. ML-4/78

$290 \pm 50$

Wood from outer part of partly rotten trunk (Pinus silvestris) found in situ in vertical position in tree cemetery ca $800 \mathrm{~m} \mathrm{NE}$ of Lącka Dune culmination, Div 7 of Protection Circle. Trunk had $21 \mathrm{~cm}$ diam, 20 annual rings, with insect burrows; most of surface had no remaining bark.

Gd-571. ML-5/78

$250 \pm 50$

Wood from outer part of trunk (Pinus silvestris) found in situ in vertical position, E part of tree cemetery on Lacka Dune, Div 7 of Protection Circle. Trunk had $20 \mathrm{~cm}$ diam, 30 annual rings; outer rings had insect burrows.

Gd-572. ML-6/78

$210 \pm 50$

Wood from outer part of trunk of Pinus silvestris found in situ in vertical position in NE part of tree cemetery, Div 9 of Protection Circle, ca $200 \mathrm{~m} \mathrm{~W}$ of tourist rte from Łebsko Lake to seashore. Trunk had $26 \mathrm{~cm}$ diam, 42 annual rings; outer rings had insect burrows to $3 \mathrm{~cm}$ depth.

Gd-1034. ML-7/78

$390 \pm 50$

Wood from outer part of basal fragment of Quercus robur, id by Kazimierz Tobolski, found at surface of fossil soil level no. 14, according to Tobolski (1975). Outcrops of this level occur in Divs 8 and 9 of Protection Circle.

\section{Gd-1038. ML-8/78}

$250 \pm 50$ soil level.

Bark from basal part of highly rotten trunk (Fagus silvatica), same fossil

General Comment (KT): results of ${ }^{14} \mathrm{C}$ dating of pine tree cemeteries agree with historical documents cited by Kobendzina (1976) which indicate increasing human activity from beginning of 17 th century AD. Other dates confirm earlier opinions (Tobolski, 1975) concerning occurrence in historical time of pine and broad leaf forests with Fagus sp dominating.

\section{Kluki profile 74 series}

Peat from coastal bog belonging to vast peatland complex extending throughout $\mathrm{N}$ area of Gardno-Leba Lowlands, profile Kluki/74 in Słowiński Natl Park, $0.5 \mathrm{~km}$ E of Kluki village $\left(54^{\circ} 40^{\prime} \mathrm{N}, 17^{\circ} 19^{\prime} \mathrm{E}\right)$ in marshy forest Vaccinio uliginosi-Pinetum, alt $2.1 \mathrm{~m}$ asl. Organic deposits, $6.7 \mathrm{~m}$ thick, overlie medium-grained sands with thin layer of detritus gyttja at base 
of organic series. N part of Gardno- $\mathrm{X}$ eba Lowlands is ref area representative of geobot unit defined by Czubiński (1950) as Coastal Region (Tobolski, 1981, p 90-93). Core Kluki/74 studies include palynol, carpol, geochem analyses, and physical sediment analysis. Core 74 coll 1974; samples subm 1978 to 1982 by Kazimierz Tobolski.

Gd-1305. Kluki $/ 74 / 25-30 \mathrm{~cm}$

$$
\mathbf{2 3 0} \pm \mathbf{5 0}
$$

Sphagnum-wood peat.

Gd-565. Kluki/74/60-65cm

$860 \pm 60$

Sphagnum peat.

Gd-1306. Kluki/74/80-85cm

$1350 \pm 60$

Carex peat.

Gd-1307. Kluki/74/100- $105 \mathrm{~cm}$

$1530 \pm 50$

Carex peat.

Gd-564. Kluki/74/120-125cm

$1750 \pm 50$

Carex peat.

Gd-1308. Kluki/74/170-174cm

$2120 \pm 50$

Transition peat.

Gd-1321. Kluki/74/190-195cm

$3080 \pm 50$

Carex peat.

Gd-563. Kluki/74/240-245cm

$3860 \pm 70$

Carex peat.

Gd-1330. Kluki/74/275-280cm

$4680 \pm 60$

Carex peat.

Gd-1315. Kluki/ $74 / 310-315 \mathrm{~cm}$

$4910 \pm 90$

Juncus peat.

Gd-1331. Kluki/74/340-345cm

$\mathbf{5 0 5 0} \pm \mathbf{5 0}$

Juncus peat.

Gd-562. Kluki/74/380-385cm

$5300 \pm 70$

Transition between Cladium and Juncus peat.

Gd-855. Kluki $/ 74 / 430-435 \mathrm{~cm}$

$6050 \pm 120$

Carex peat.

Gd-1323. Kluki/ $74 / 460-465 \mathrm{~cm}$

$6670 \pm 60$

Carex peat. 
Cladium peat.

Gd-1322. Kluki/ $74 / 540-545 \mathrm{~cm}$

Cladium peat.

Gd-547. Kluki/74/575-580cm

Cladium peat.

Gd-1329. Kluki $/ 74 / 630-635 \mathrm{~cm}$

$9110 \pm 70$

Cladium peat.

Gd-548. Kluki $/ 74 / 660-665 \mathrm{~cm}$

$9870 \pm 110$

Carex peat with gyttja.

General Comment (KT): according to palynol and ${ }^{14} \mathrm{C}$ data, beginning of organic deposition can be assigned to older part of Pre-boreal period. Since then, few distinctive minerotrophic phytocenoses contributed to deposition of various peat layers. Oligotrophication began ca $1000 \mathrm{yr}$ BP. Modern bog pine forests phytocenosis growing on bog is estimated to be very young; most probably this pine stand constitutes first tree generation (Tobolshi, 1982, p 133).

\section{Kluki KL/2 series}

Peat from supplementary profile taken ca $2.5 \mathrm{~km} \mathrm{~N}$ of profile Kluki/ 74. Coll and subm 1981 by Kazimierz Tobolski.

Gd-1291. Kluki KL/2/2/150-155cm

Gd-830. Kluki KL/2/1/205-210cm

\section{e. Vistula Deltaic area}

\section{Druzno profile 1a series}

Peat and gyttja from basal series of organogenic sediments, profile $1 \mathrm{a}$, in Druzno Lake basin $\left(54^{\circ} 10^{\prime} \mathrm{N}, 19^{\circ} 30^{\prime} \mathrm{E}\right)$, ca $10 \mathrm{~km} \mathrm{SSE}$ of Elbląg, Żuławy. Coll March 1979 by Kazimierz Więckowski and Joanna Zachowicz; subm 1979 by JZ, Inst Meteorol and Water Management, Gdynia. Lake Druzno is in central part of catchment basin of Elblag R, surrounded by Malbork Żuławy, Vistula Lagoon, and Elblag Upland, in depression $1.8 \mathrm{~m}$ below sea level. Lake is shallow, max depth $3 \mathrm{~m}$, lake basin filled with layer of gyttja, 6 to $8 \mathrm{~m}$ thick (Mikulski, 1955). Present studies include palynol, diatom, physical and chemical analyses (Przybyłowska-Lange, 1976; Zachowicz, 1981; Zachowicz, Przybyłowska-Lang \& Nagler, 1982).

Gd-1131， Druzno 1a-1

$$
6440 \pm 50
$$

Black-brown peat with fragments of undecomposed leaves and twigs, depth 625 to $635 \mathrm{~cm}$. 
Gd-1128. Druzno 1a-2

$6390 \pm 140$

Wood from tree trunk, $10 \mathrm{~cm}$ diam, depth 646 to $655 \mathrm{~cm}$.

Gd-1132. Druzno 1a-3:sol

$7050 \pm 70$ fraction.

Brown-gray coarse detritus gyttja, depth 679 to $688 \mathrm{~cm}$, alkali-soluble

Gd-715. Druzno 1a-3:ins

$6430 \pm 180$

Same sample, insoluble fraction. Comment: undersized, diluted.

Gd-1136. Druzno 1a-4:sol

$8990 \pm 80$

Well-decomposed brown peat, depth 712 to $722 \mathrm{~cm}$, alkali-soluble fraction.

Gd-716. Druzno 1a-4:ins

$8760 \pm 220$

Same sample, insoluble fraction. Comment: undersized, diluted.

Gd-1137. Druzno 1a-5

$11,290 \pm 110$

Black-brown peat with sand, lowermost layer, depth 858 to $866 \mathrm{~cm}$.

Region 12. Eastern Pomerania

a. Dobrzyń Lake District

Reference site: Lake Steklin

Steklin is in SW part of Dobrzyń Lake dist (Dobrzyń Moraine Plateau), ca $23 \mathrm{~km}$ ESE of Torun, comprising Lake Steklin $\left(52^{\circ} 58^{\prime} \mathrm{N}, 19^{\circ} \mathrm{E}\right)$ and peat bog in W part of Lake channel (Noryśkiewicz, 1982).

Gd-1115. Lake Steklin 920-928

$11,630 \pm 110$

Silt with plant detritus, depth 920 to $928 \mathrm{~cm}$, lowermost part of basal deposits of total thickness, $940 \mathrm{~cm}$, W part of Lake Steklin. Coll Feb 1978 and subm 1979 by Bożena Noryśkiewicz, Inst Biol, Mikołaj Kopernik Univ, Toruń.

\section{Steklin peatbog series}

Peat from profile taken at W part of Lake Steklin channel. Coll and subm 1980 by Bożena Noryśkiewicz.

Gd-840. Steklin $110 \mathrm{~cm}$

$$
\begin{array}{r}
750 \pm 90 \\
1870 \pm 60 \\
2330 \pm 120 \\
4470 \pm 60
\end{array}
$$

Gd-841. Steklin $230 \mathrm{~cm}$

Gd-842. Steklin $340 \mathrm{~cm}$

Gd-1303. Steklin $420 \mathrm{~cm}$

b. Olsztyn Lake District

Reference site: Woryty 


\section{Woryty profile 80 s series}

Gyttja and peat from continuous profile of organic sediments with variable content of $\mathrm{CaCO}_{3}$ filling bipartite overgrown channel lake in Woryty village $\left(53^{\circ} 45^{\prime} \mathrm{N}, 20^{\circ} 10^{\prime} \mathrm{E}\right)$, center of subregion $12 \mathrm{~b}$, ca $17 \mathrm{~km}$ WSW of Olsztyn, 2km WNW of Gietrzwałd, hilly area bordered by Pasłęka, Old Pasłęka, and Giłwa Rivers, close to settlement complex of Lusatian culture from IV-VI periods of Bronze age (Dąbrowski, 1981; Dąbrowski \& Mogielnicka-Urban, 1976). Core Woryty 80 coll 1974 by Kazimierz Więckowski and Magdalena Ralska-Jasiewiczowa (Cieśla, Ralska-Jasiewiczowa, \& Stupnicka, 1978), and core Woryty 80s coll 1979 by G Digerfeldt and T Persson and MRJ. Six samples from core 80 were subm and dated in Cambridge (Ralska-Jasiewiczowa et al, $\mathrm{ms}$ in preparation), chronology of core $80 \mathrm{~s}$ is based on $17^{14} \mathrm{C}$ dated samples, 5 dated in Lund (R, 1981, v 23, p 392-393; Pawlikowski et al, 1982) and 12 in Gliwice. Thirteen local pollen assemblage zones (PAZ) were distinguished, some with subzones based on cluster analysis (Gordon \& Birks, 1972).

\section{Gd-1190. Woryty $80 \mathrm{~s} / 136-139 \mathrm{~cm}$}

$2080 \pm 80$

Swamp peat with gyttja, PAZ W-12, high Carpinus pollen percentage, subzone $\mathrm{W}-12 \mathrm{~b}$, decrease in pollen concentration and increase in NAP pollen percents with predominant Gramincae, Artemisia, Plantago lanceolata, and Rumex acetosella. Comment (MRJ): this subzone reflects entry of new cultural group into Woryty area.

\section{Gd-1192. Woryty $80 \mathrm{~s} / 176-179 \mathrm{~cm}$}

$2320 \pm 60$

Same, just below upper boundary of PAZ W-1 1. Comment (MRJ): lower boundary of PAZ W-1 l can be dated to ca 3500 BP. Pollen spectrum shows long-lasting settlement phase of Late Bronze Lusatian culture with dominance of pastoral economy.

\section{Gd-1191. Woryty $80 \mathrm{~s} / 316-319 \mathrm{~cm}$}

$3960 \pm 70$

Dark brown peaty gyttja with some silt, PAZ W-10.

\section{Gd-1193. Woryty $80 \mathrm{~s} / 406-409 \mathrm{~cm}$}

Dark-brown gelatinous sapropelic sediment, lower boundary of PAZ $\mathrm{W}-10$. Comment (MRJ): first pollen grains of cereals indicate presence of human settlement near lake, deciduous forest became more open, dominated by oak with abundant hazel understory.

Gd-727. Woryty $80 \mathrm{~s} / 426-429 \mathrm{~cm}$

$\mathbf{5 8 9 0} \pm \mathbf{9 0}$

Same, PAZ W-9. Comment (MRJ): rise in pollen concentration, probably resulting from decreased sedimentation rate.

Gd-1194. Woryty $80 \mathrm{~s} / 476-479 \mathrm{~cm}$

$6460 \pm 70$

Same, PAZ W-10. Comment (MRJ): slow decrease in Ulmus and increase in Quercus pollen values between $6460 \mathrm{BP}$ and $5120 \mathrm{BP}$ with change in sediment suggest lowered water level in lake and indicate phase of warm but drier climate. 
Gray-olive slightly porous detritus gyttja with calcium carbonate, PAZ W-8 with dominant pollens of Pinus and Alnus. Comment (MFP): undersized, diluted.

Gd-1198. Woryty $80 \mathrm{~s} / 616-619 \mathrm{~cm}$ W-8.

Dark-brown dy-like silty sediment, overlying lower boundary of PAZ

Gd-800. Woryty $80 \mathrm{~s} / 665-678 \mathrm{~cm}$

$10,320 \pm 220$

Gray-olive silty gyttja with some $\mathrm{CaCO}_{3}$ and patches of partly disintegrated shells, PAZ W-7. Comment (MRJ): older than expected.

Gd-1265. Woryty $80 \mathrm{~s} / 810-820 \mathrm{~cm}$

$11,210 \pm 90$

Dark-brown gelatinous calcareous gyttja, top of layer. Comment (MRJ): older than expected.

\section{Gd-801. Woryty $80 \mathrm{~s} / 868-885 \mathrm{~cm}$}

$10,450 \pm 300$

Black ferruginous gyttja with mollusk shells. Comment (MFP): undersized, diluted.

\section{Gd-802. Woryty $80 \mathrm{~s} / 920-930 \mathrm{~cm}$}

$10,430 \pm 300$ diluted.

Gray ferruginous gyttja, top of layer. Comment (MFP): undersized,

General Comment (MRJ): dates Gd-800, -801 , and -1265 were not taken into account in establishing absolute chronology of profile 80s.

RFFFRENCES

Bałaga, Krystyna, 1982, Vegetational history of the Lake Xukcze environment (Lublin Polesie E Poland) during the Late Glacial and Holocene: Acta Palaeobot, v 22, no. 1, p 7-22.

Berglund, B E, ed, 1979, Palacohydrological changes in the temperate zone in the last 15,000 years. Subproject B. Lake and mire environments: Proj Guide 1. Dept Quaternary Geol, Univ Lund, Lund, Sweden, $123 \mathrm{p}$.

Borówka, R K and Tobolski, Kazimierı, 1979, Nowe znaleziska archeologiczne na Mierzei Xebskiej i ich znaczenie dla paleogeografii tego obszaru: Bad Fizjogr nad Polską Zach, ser A, v 32, p $21-29$.

Brykczyńska, Ewa, 1978, Próba odtworzenia rozwoju roślinności w późnym glacjale i holocenie w okolicach Niechorza na Pomorzu Zachodnim: Kwart geol, v 22, p 36 l-377.

Cieśla, A, Ralska-Jasicwiczowa, Magdalena, and Stupnicka, Ewa, 1978, Paleobotanical and geochemical investigations of the lacustrine deposits at Woryty near Olsztyn (NE Poland): Pol Arch Hydrobiol, v 25, p $61-73$.

Currie, L. A and Polach, H A, 1980, Exploratory analysis of the international radiocarbon cross-calibration data: consensus values and interlaboratory error. Preliminary note, in Stuiver, Minze and Kra, Renee, eds, Internatl radiocarbon conf, 10th, Proc: Radiocarbon, v 22, no. 3, p 933-935.

Czubiński, Zygmunt, 1950, Zagadnienia geobotaniczne Pomorza: Bad Fizjogr nad PolskąZach, v 2, no. 4, p 439-658.

Dabrowski, Jan, ed, 1981, Woryty-studium archeologiczno-przyrodnicze zespołu osadniczego kultury łużyckicj: Pol Bad Archeol, v 20, p 1-256.

Dąbrowski, Jan and Mogielnicka-Urban, M, 1976, Wyniki prac wykopaliskowych na stanowiskach zespołu osadniczego kultury łuzyckiej we wsi Woryty, woj Olsztyn: Spraw Archeol, v 22, p 145-167.

Gordon, A D and Birks, H J B, 1972, Numerical methods in Quaternary palacoecology. I. Zonation of pollen diagrams: New Phytol, v 71, p $961-979$.

Håkansson, Sören, 1976, University of Lund radiocarbon dates IX: Radiocarbon, v 18, p 290320 . 
Håkansson, Sören, 1980, University of Lund radiocarbon dates XIII: Radiocarbon, v 22, p 1045-1063.

403 - 1981, University of Lund radiocarbon dates XIV: Radiocarbon, v 23, p 384-

Hjelmroos, Mervi, 1981a, Holocene history of Lake Wielkie Gacno and its surroundings, in Kozarski, Stefan and Tobolski, Kazimierz, eds, Paleohydrology of the temperate zone, symposium: Guide-book of excursion; Poznań, Adam Mickiewicz Univ, p 76-88.

1981b, The Post-Glacial development of Lake Wielkie Gacno, NW Poland. The human impact on the natural vegetation: Acta Palaeobot, v 21, no. 2, p 129-144.

1982, The Holocene development of Lake Wielkie Gacno, NW Poland, a palaeoecological study. Preliminary results: Acta Palaeobot, v 22, no. 1, p 23-46.

Jankowska, Barbara, 1981, History of vegetation and settlement development at the Gopło Lake in the light of pollen analysis, in Paleohydrology of the temperate zone, symposium: Abs of papers, Poznań, Adam Mickiewicz Univ, p 68-69.

Kobendzina, Jadwiga, 1976, Z geografii historycznej Łeby i okolicy: Przegląd geog, v 48, p $689-701$.

Kopczyńska-Lamparska, Krystyna, 1974, Genesis and stratigraphy of tills of the cliff near Rewal: Uniw Adama Mickiewicza, zesz nauk, ser geog, v 10, p 167-176.

1976 , Radiocarbon datings of the Late Glacial and Holocene deposits of Western Pomerania: Acta geol pol, v 26, p 413-418.

Koperowa, Wanda, 1962, Późnoglacjalna i holoceńska historia roślinności Kotliny Nowotarskiej: Acta Palaeobot, v 2, no. 3, p 3-57.

Kuźniewski, Edward, 1959, Torfowisko Zieleniec koło Dusznik: Rocznik Kłodzki, v 3, p $169-$ 211 .

_ 1962, Analiza palinologiczna torfowiska Zieleniec koło Dusznik: Kwart Opolski, zesz przyrodn, no. 2, p 115-143.

Latałowa, Małgorzata, 1981a, Local and regional aspects of paleobotanical material from the Lake Zarnowiec area, in Kozarski, Stefan and Tobolski, Kazimierz, eds, Paleohydrology of the temperate zone, symposium: Guide-book of excursions, Poznań, Adam Mickiewicz Univ, p $116-120$.

_ $1981 \mathrm{~b}$, The vegetational history of the Lake Żarnowiec area (eastern part of the Baltic coastal zone in Poland), in Paleohydrology of the temperate zone, symposium: Abs of papers, Poznań, Adam Mickiewicz Univ, p 70-71.

- 1982a, Major aspects of the vegetational history in the eastern Baltic coastal zone of Poland: Acta Palaeobot, v 22, no. 1, p 47-63.

$1982 \mathrm{~b}$, Postglacial vegetational changes in the eastern Baltic coastal zone of Poland: Acta Palaeobot, v 22, no. 2, p 179-249.

Maruszczak, Henryk, 1966, Zagadnienia genezy i wieku jezior Łęczyńsko-Włodawskich: Folia Soc Sci Lubliniensis, ser D, no. 5/6, p 31-37.

Mikulski, J S, 1955, Jezioro Druzno-proba charakterystyki limnologicznej: Ekologia Polska, ser A, v 3 , no. 1, p $1-31$.

Noryśkiewicz, Bożena, 1982, Lake Steklin-a reference site for the Dobrzyń-Chełmno Lake District, N Poland. Report on palaeoecological studies for the IGCP Project No. 158B: Acta Palacobot, v 22, no. 1, p 65-83.

Pawlikowski, M, Ralska-Jasiewiczowa, Magdalena, Schönborn, W, Stupnicka, Ewa, and Szeroczyńska, Krystyna, 1982, Woryty near Gietrzwałd, Olsztyn Lake District, NE Polandvegetational history and lake development during the last 12,000 years: Acta Palacobot, v 22, no. 1, p 85-116.

Pazdur, Anna, Awsiuk, Romuald, Bluszcz, Andrzej, Pazdur, M F, Walanus, Adam, and Zastawny, Andrzej, 1982, Gliwice radiocarbon dates VII: Radiocarbon, v 24, p 171-181.

Pazdur, Anna, Pazdur, M F, and Zastawny, Andrzej, 1979, Gliwice radiocarbon dates V: Radiocarbon, v 21, p 165-170.

Pazdur, M F, 1982, Badanie dokładności datowania metodạ ${ }^{14} \mathrm{C}$ późnoplejstoceńskich i holoceńskich osadów organogenichznych: Pol Sląka, zesz nauk, ser mat-fiż, no. 41, p $1-81$.

Pazdur, M F, Awsiuk, Romuald, Bluszcz, Andrzej, Pazdur, Anna, Walanus, Adam, and Zastawny, Andrzej, 1983, Gliwice radiocarbon dates IX: Radiocarbon, v 25, p 843-866.

Pazdur, M F and Walanus, Adam, 1979, Statistical analysis of data and age calculation in Gliwice Radiocarbon Laboratory: Muz Archeol i Etnogr w Lodzi, prace i materiały, ser archeol, v 26, p 283-289.

Polach, H A, 1979, Correlation of ${ }^{14} \mathrm{C}$ activity of NBS oxalic acid with Arizona 1850 wood and ANU sucrose standards, in Berger, Rainer and Suess, H E, eds, Radiocarbon dating, Internatl radiocarbon conf, 9th, Proc: Berkeley/Los Angeles, Univ California Press, p 115-124.

Przybyłowska-Lange, Weisława, 1976, Diatoms of the lake deposits from the Polish Baltic Coast. I. Lake Druzno: Acta Palaeobot, v 17, no. 2, p 35-74. 
Ralska-Jasiewiczowa, Magdalena, 1981, Polish working group IGCP 158B. Report on the results of research 1978-1981, in Paleohydrology of the temperate zone, symposium: Abs of papers, Poznań, Adam Mickiewicz Univ, p 39-40.

___ 1982, Introductory remarks: Acta Palaeobot, v 22, no. 1, p 3-6.

Stark, L, 1936, Zur Geschichte der Moore und Wälder Schlesiens in postglazialer Zeit: Englers Bot Jahrb, v 67, p 493-640.

Szafer, Władysław, 1948, Późny glacjał w Roztokach pod Jasłem: Starunia, no. 26, p 1-29.

Szczepanek, Kazimierz, 1961, Późnoglacjalna i holoceńska historia roślinności Gór Swiętokrzyskich: Acta Palaeobot, v 2, no. 2, p 1-45.

1982, Development of the peat-bog at SYopiec and the vegetational history of the Swiętokrzyskie (Holy Cross) Mts in the last 10,000 years. Preliminary results: Acta Palaeobot, v 22, no. 1, p $117-130$.

Tobolski, Kazimierz, 1972, Wiek i geneza wydm przy południowowschodnim brzegu jeziora Xebsko: Bad Fizjogr nad Polska Zach, ser B, v 25, p 135-146.

1975, Studium palinologiczne gleb kopalnych Mierzei Łebskiej w SYowińskim Parku Narodowym: Pozn Tow Przyj Nauk, kom biol, prace, v 41, p 1-76.

1979, Zmiany lokalnej szaty roślinnej na podstawie badán subfosylnych osadów biogenicznych w strefie plaży koło Keby: Bad Fizjogr nad polską Zach, ser A, v 32, p 151168 .

1980, The fossil soils of the coastal dunes on the Keba Bar and their paleogeographical interpretation: Quaestiones Geog, v 6, p 83-97.

1981, The Gardno-Keba Plain, in Kozarski, Stefan and Tobolski, Kazimierz, eds, Paleohydrology of the temperate zone, symposium: Guide-book of excursions, Poznań, Adam Mickiewicz Univ, p 89-115.

1982. Anthropogenic changes in vegetation of the Gardno-Keba Lowland, N Poland. Preliminary report: Acta Palaeobot, v 22, no. 1, p 131-139.

Tobolski, Kazimierz, Pazdur, M F, Pazdur, Anna, Awsiuk, Romuald, Bluszcz, Andrzej, and Walanus, Adam, 1980, Datowanie metoda ${ }^{14} \mathrm{C}$ subfosylnych drewien występujacych na mierzejach Niziny Garnieńsko-Kebskiej: Bad Fizjogr nad Polską Zach, ser A, v 33, p 133 148 .

Wilgat, T, 1953, Jeziora Łęczyńsko-Włodawskie: Ann UMCS, ser B, v 8, no. 3, p 1-121.

Wojterski, Teofil, 1964, Bory sosnowe na wydmach nadmorskich na Polskim Wybrzeżu: Pozn Tow Przyj Nauk, kom biol, prace, v 28, no. 2, p 1-217.

Zachowicz, Joanna, 1981, The Late-Glacial and Holocene vegetational history of the Żuławy Region (North Poland) in the light of a biostratigraphic study of Lake Druzno, in Paleohydrology of the temperate zone, symposium: Abs of papers, Poznań, Adam Mickiewicz Univ, p 88.

Zachowicz, Joanna, Przybyłowska-Lange, Wiesława, and Nagler, J, 1982, The Late-Glacial and Holocene vegetational history of the Zuławy Region, N Poland. A biostratigraphic study of Lake Druzno sediments: Acta Palaeobot, v 22, no. 1, p 141-161. 